\title{
KAJIAN YURIDIS PENGGUNAAN GANJA SEBAGAI METODE KESEHATAN DIKAITKAN DENGAN UNDANG-UNDANG NOMOR 36 TAHUN 2009 TENTANG KESEHATAN JO UNDANG-UNDANG NOMOR 35 TAHUN 2009 TENTANG NARKOTIKA
}

\author{
Oleh : Rani Dewi Kurniawati ${ }^{1}$ \\ Fahmi Ihwani Fadilah
}

\begin{abstract}
ABSTRAK
Sebagian masyarakat di Indonesia saat ini berpendapat kalau ganja adalah tanaman yang bisa menjerumuskan manusia dalam hidup yang penuh dosa, penyakit dan kecanduan. Ganja juga dikenal secara negatif oleh masyarakat sebagai tanaman yang mendekatkan kematian, tanaman yang dicari dan diburu oleh pemakainya hanya untuk kesenangan sesaat. Sehingga yang terjadi tidak sesuai dengan yang di harapkan oleh masyarakat ketika mereka berupaya mempertahankan hidup dengan memanfaatkan ganja untuk kesehatan, mereka justru terhalang oleh beberapa paradigma negatif yang menyebutkan bahwa ganja sepenuhnya tanaman yang berbahaya. Masalah yang akan dituangkan adalah bagaimana proses penggunaan ganja sebagai metode kesehatan serta bagaimana akibat hukum jika pemanfaatan tanaman ganja dijadikan sebuah metode atau alternatif untuk kesehatan.

Pendekatan yang digunakan adalah pendekatan yuridis normatif. Data yang digunakan dalam penelitian ini adalah data sekunder yang diperoleh dari studi literatur. Setelah data terkumpul, kemudian dianalisis secara kualitatif.

Masyarakat sampai saat ini masih menggunakan ganja untuk berbagai kebutuhan termasuk di dalamnya untuk metode pengobatan. Dalam literatur kebudayaan di Indonesia, ganja digunakan sejak dahulu kala dan turun-temurun. Akan tetapi banyaknya penyalahgunaan ganja, sehingga penggunaan ganja di Indonesia masih harus dihadapkan dengan hukum yang di dalam undang-undang tersebut tidak disebutkan bahwa ada izin penggunaan ganja untuk segi medis karena alasan belum adanya riset bahwa ganja aman dikonsumsi.
\end{abstract}

Kata Kunci : Ganja, Metode Kesehatan, Akibat Hukum

\footnotetext{
${ }^{1}$ Dosen Fakultas Hukum Universitas Majalengka
} 


\section{A. Latar Belakang Masalah}

Sebagian masyarakat di Indonesia saat ini berpendapat kalau ganja adalah tanaman berbahaya yang bisa menjerumuskan manusia dalam hidup yang penuh dosa, penyakit, dan kecanduan. Ganja juga dikenal secara negatif oleh masyarakat sebagai tanaman yang mendekatkan kematian, tanaman yang dicari dan diburu oleh pemakainya hanya demi kesenangan sesaat. Sebaliknya beberapa orang berpendapat bahwa ganja bisa menghadirkan rasa santai, senang, dan bahagia, mengalirkan inspirasi, mengusir penat, bosan, bahkan depresi dan stress. Bahkan ada anggapan lain yang menganggap bahwa ganja sebagai obat ampuh untuk mengusir berbagai jenis rasa sakit dan menghambat laju dari penyakit-penyakit mematikan. $^{2}$

Terkait dengan paparan di atas, belasan ribu tahun adalah waktu yang sangat panjang bila dibandingkan dengan beberapa dekade sejak ganja telah terusir secara hukum dari ruang publik dan dihapus dari kesadaran masyarakat oleh kampanye media. Seperti membandingkan hari yang panjang dengan satu kedipan mata, namun dalam kedipan mata inilah kita hidup dan berusaha memaknai zaman yang penuh tanda tanya. ${ }^{3}$

Kesejarahan, ganja pertama kali ditemukan di Cina pada tahun 2737 SM. Di Cina, orang pertama kali menanamnya secara bersamaan. Masyarakat Cina telah mengenal ganja sejak zaman batu. Mereka menggunakannya dalam kehidupan

2 Dhira Narayana (et.all), Hikayat Pohon Ganja , PT Gramedia Pustaka Utama, Jakarta, 2011, hlm. 1.

${ }^{3}$ Ibid., hlm. 2 sehari-hari, sama halnya dengan bahan pakaian, pukat, obat-obatan, dan terapi penyembuhan seperti penyakit rematik, sakit, perut, beriberi hingga malaria, juga digunakan untuk minyak lampu dan bahan untuk upacara

keagamaan. ${ }^{4}$ Seiring dengan perkembangan dunia medis dan industri, Negara-negara maju mulai mempertimbangkan untuk menjadikan serat ganja sebagai bahan minyak bakar karena prosesnya yang mudah dan aman dari kebakaran. Karena kandungan minyaknya yang aman dan lain dari minyak olahan biasa seperti pula layaknya minyak kelapa. Secara medis, komposisi kimia yang terkandung dalam ganja adalah cannabinol. Cannabinol atau THC yang terdiri dari Delta -9- THC dan Delta -8- THC. Delta -9- THC sendiri, mempengaruhi pola pikir otak manusia melalui cara melihat sesuatu, mendengar, dan mempengaruhi suasana hati pemakainya.

Delta -9- THC diyakini para ilmuwan medis juga mampu mengobati berbagai macam penyakit, seperti daun dan biji, untuk membantu penyembuhan penyakit tumor dan kanker. Akar dan batangnya, bisa dibuat menjadi jamu yang mampu menyembuhkan penyakit kejang perut, disentri, anthrax, asma, keracunan darah, batuk, diare, luka bakar, bronkritis, dan masih banyak lagi yang bisa digunakan dari bagian tanaman ini. ${ }^{5}$ Namun yang terjadi nyatanya tidak sesuai dengan yang diharapkan oleh masyarakat ketika mereka berupaya

${ }^{4}$ Abdul Khaliq, Dunia Dalam Ganja, Penerbit Katalika, Yogyakarta, 2017, hlm. 19.

${ }^{5}$ Ibid, hlm. 22. 
untuk mempertahankan hidup dengan memanfaatkan tanaman ganja untuk kesehatan, mereka justru terhalang oleh beberapa paradigma negatif yang menyebutkan bahwa tanaman ganja tidak dapat menjadi salah satu dari sekian banyaknya tanaman tradisional yang dapat digunakan sebagai alternatif.

Berdasarkan apa yang telah diuraikan di atas, maka penulis tertarik untuk melakukan penelitian dengan judul "KAJIAN YURIDIS PENGGUNAAN GANJA SEBAGAI METODE KESEHATAN DIKAITKAN DENGAN UNDANG-UNDANG $\begin{array}{llll}\text { NOMOR } 36 & \text { TAHUN } 2009\end{array}$ TENTANG KESEHATAN JO UNDANG-UNDANG NOMOR 35 TAHUN 2009 TENTANG NARKOTIKA"

\section{B. Rumusan Masalah}

Berdasarkan latar belakang yang diuraikan di atas, maka dapat dirumuskan beberapa masalah dalam penelitian ini. Adapun permasalahannya adalah sebagai berikut :

1. Bagaimana proses penggunaan ganja sebagai metode kesehatan?

2. Bagaimana akibat hukum jika pemanfaatan ganja dijadikan sebuah metode atau alternatif untuk upaya kesehatan?

\section{Tujuan Penelitian} adalah :

Adapun tujuan dari penelitian ini

1. Untuk mengetahui proses penggunaan ganja sebagai metode kesehatan.

2. Untuk mengetahui akibat hukum jika pemanfaatan ganja dijadikan sebuah metode atau alternatif untuk upaya kesehatan.

\section{Kerangka Pemikiran}

Perdebatan mengenai penggolongan sebuah tanaman yang dikategorikan sebagai salah satu dari bagian narkotika golongan satu banyak diperbincangkan ketika seseorang terjerat hukum karena akibat dari penggunaan ganja, karena ganja dimasukan pada jenis narkotika golongan satu yang diantaranya jenis narkotika yang secara umum dikenal masyarakat antara lain Ganja, Sabusabu, Kokain,Opium, Heroin, dan lain-lain.

Undang-undang Dasar Negra Republik Indonesia dalam Pasal 28 A, dijelaskan bahwa "Setiap warga negara berhak untuk hidup dan kehidupannya". Hal tersebut menunjukan bahwa cita-cita negara Indonesia dala mensejahterakan rakyatnya dibutuhkan sebuah kebebasan dalam pemenuhan kehidupannya. $^{6}$

$$
\text { Menurut Undang-Undang }
$$
Nomor 35 Tahun 2009 Tentang Narkotika Pasal 113 ayat (2) dalam hal perbuatan memproduksi, mengimpor, mengekspor, atau menyalurkan Narkotika Golongan I sebagaimana dimaksud pada ayat (1) dalam bentuk tanaman beratnya melebihi 1 (satu) kilogram atau melebihi 5 (lima) batang pohon atau dalam bentuk bukan tanaman beratnya melebihi 5 (lima) gram, pelaku dipidana dengan pidana mati, pidana penjara seumur hidup, atau pidana penjara paling singkat 5 (lima) tahun dan paling lama 20 (dua puluh)

6 Undang-Undang Dasar Negara Republik Indonesia Pasal 28 A. 
tahun dan pidana denda maksimum sebagaimana dimaksud pada ayat (1) ditambah $1 / 3$ (sepertiga). ${ }^{7}$

Sebagai negara hukum, kita dapat memperoleh pembuktian dan fakta-fakta terkait kasus penyalahgunaan narkotika di persidangan yang banyak menyita perhatian masyarakat ketika seseorang terjerat hukum hanya karena upaya yang dilakukan dengan cara menggunakan tanaman yang dilarang oleh negara.

Untuk mempermudah dalam mela-kukan pengkajian dan pembahasan Penelitian ini, penulis mengaitkan dengan beberapa teori diantaranya:

1. Teori negara hukum

Dalam Pasal 1 ayat (3) Undang-Undang Dasar Negara Kesatuan Republik Indonesia Tahun 1945 menyebutkan, bahwa "Negara Indonesia adalah negara hukum" kekuasaan negara indonesia dijalankan melalui hukum yang berlaku di indonesia. semua aspek kehidupan sudah diatur melalui hukum yang sah sehingga hal ini mampu mencegah konflik yang terjadi diantara warga negara. $^{8}$

2. Teori Hak Asasi Manusia

Hak asasi manusia dipandang sebagai hak Kodrati (hak yang sudah melekat pada manusia sejak lahir) dan jika manusia tersebut meninggal maka hak-hak yang dimilikinya pun akan hilang. Hak Asasi Manusia dimiliki secara otonom (Independent) terlepas dari pengaruh Negara sehingga tidak

7 Undang-Undang Nomor 35 Tahun 2009 Tentang Narkotika

8 Undang-Undang Dasar Negara Kesatuan Republik Indonesia Pasal 1 Ayat 3 ada alasan Negara untuk membatasi HAM tersebut. ${ }^{9}$

3. Teori Kesehatan

Organisasi Kesehatan Dunia WHO, (World Health Organization) mendefinisikan sehat sebagai suatu keadaan fisik, mental dan sosial yang sejahtera dan bukan hanya ketiadaan penyakit dan lemah. Meskipun berguna dan tepat, definisi ini dianggap terlalu ideal dan tidak nyata. Kalau menggunakan definisi WHO $70-95 \%$ orang di dunia sebagai tidak sehat. ${ }^{10}$

\section{E. Metode Penelitian}

Metode penelitian yang digunakan dalam penelitian ini sebagai berikut :

1. Spesifikasi Penelitian

Penelitian ini menggunakan metode deskriptif analisis, yang menggam-barkan atau melukiskan peraturan perundangundangan yang berlaku yang dikaitkan dan dianalisis dengan teori ilmu hukum dan suatu keadaan atau objek tertentu secara faktual.

2. Metode Pendekatan

Pendekatan yang digunakan dalam penelitian ini adalah pendekatan yuridis normatif, yaitu merupakan penelitian kepustakaan, atau penelitian terhadap data sekunder, atau

${ }^{9}$ Scott Davidson, Hak Asasi Manusia, Grafiti, Jakarta, 1994 , hlm. 37.

10

http://derysmono.blogspot.com/2013/12/ teori-kesehatan.html diakses pada tanggal $10 / 12 / 2018$ 
penelitian yang dilakukan dan ditujukan hanya kepada peraturan-peraturan tertulis atau bahan-bahan hukum lainnya.

3. Tahap penelitian

a. Studi pustaka

Mencari referensi terhadap bahan-bahan hukum yang diperlukan, melakukan pencatatan dan pembuatan data ikhtisar yang berisikan berbagai pengertian dan pendapat para ahli tentang penulisan Penelitian ini.

b. Penelitian lapangan

Mencari data-data dilapangan untuk memperoleh informasi yang dibutuhkan dalam pembuatan Penelitian ini. Data yang diperoleh dari lapangan berupa data dari tokoh maupun dari masyarakat.

4. Teknik Pengumpulan data

a. Data primer, yaitu data yang diperoleh secara langsung dari lapangan guna menunjang data sekunder, sehingga dari data primer akan dapat diketahui bagaimana pelaksanaan penggunaan ganja sebagai metode kesehatan

b. Studi kepustakaan

Melakukan studi kepustakaan dipergunakan untuk memperoleh data teoritis maupun hasil-hasil penelitian guna mempertajam analisis mengenai masalah penelitian. Teknik ini juga digunakan untuk memberi arahan dengan mempelajari masalah yang diteliti dari buku-buku, majalah-majalah, dan surat kabar yang ada hubungannya dengan masalah yang diteliti.

5. Alat Pengumpulan Data

Alat pengumpulan data yang digunakan penulis adalah studi kepustakaan, yaitu mengumpulkan sumber-sumber dari buku-buku untuk mendapatkan data yang terkait dengan masalah.

6. Analisis Data

Analisis data dan penarikan kesimpulan yang digunakan dalam penelitian ini adalah analisis secara kualitatif. Hal ini bertujuan untuk menggambarkan mengenai proses masyarakat menggunakan ganja sebagai metode kesehatan dan akibat daripada hukum di Indonesia jika pemanfaatan ganja dijadikan sebuah metode atau alternatif untuk upaya kesehatan.

7. Lokasi Penelitian
a. Perpustakaan
Universitas
Majalengka
b. Perpustakaan Daerah
Kabupaten Majalengka

\section{F. Pembahasan Proses Masyarakat Menggunakan Ganja Sebagai Metode Kesehatan}

\section{Proses Penggunaan Ganja Sebagai Metode Kesehatan}

Penggunaan ganja tidak pernah menimbulkan masalah besar di Indonesia, namun kebijakan prohibitionist (pelarangan) tetap diberlakukan sampai sekarang. Meskipun prevalensi konsumsi ganja cukup tinggi, diskusi lokal atau 
nasional terkait kebijakan ganja jarang sekali dilakukan. Hal ini juga diperburuk oleh sikap anti-narkotika serta kegagalan institusi publik dalam merancang dan menerapkan kebijakan yang berbasis ilmiah. Karena perundang-undangan antinarkotika yang berlaku saat ini, terdapat banyak hambatan dalam proses penelitian tentang ganja, baik dari segi medis maupun antropologi. Penggunaan ganja tradisional di Indonesia kebanyakan ditemukan di bagian utara pulau Sumatera, khususnya di wilayah Aceh. Pembatasan dalam produksi, penggunaan, dan distribusi ganja diprakarsai oleh pemerintah kolonial Belanda pada tahun 1920-an, menyusul aksi-aksi pengendalian ganja pada skala internasional. ${ }^{11}$

Selama ini, pendapat umum terlanjur didominasi oleh pandangan yang sepenuhnya negatif tentang ganja. Pemahaman itu terbentuk sebagai hasil kampanye antinarkotika; salah satunya adalah gambar daun ganja dengan tengkorak yang disebarkan dimana-mana. Dengan begitu banyak fakta tentang manfaat dan kegunaan ganja bagi kehidupan manusia sungguh merupakan sesuatu yang tidak saja keterlaluan, tetapi juga memalukan dan melecehkan rasa keadilan dan kemanusiaan jika seluruh pihak "berwajib" tetap bersikukuh untuk menyatakan bahwa ganja adalah "barang haram", "sumber bencana", "penyakit masyarakat", "perusak masa depan", bahkan "tiket menuju neraka" dan dengan begitu tetap

\section{1}

https://www.tni.org/en/publication/ganja-diindonesia, diakses pada hari Minggu tanggal 09 Desember 2018, pukul 21.08 WIB. bersikukuhmenangkapi dan memenjarakan warga yang menggunakan ganja untuk berbagi keperluan. ${ }^{12}$

Seperti jenis-jenis tanaman berbunga tertentu yang sangat bergantung kepada lebah dan kupukupu jenis tertentu juga, tanaman ganja telah menciptakan simbiosis mutualisme yang panjang dan menakjubkan dengan manusia. ${ }^{13}$

Dalam langkah-langkah peradaban manusia berikutnya, kebutuhan akan zat memabukan ternyata bukan satu-satunya yang mendorong meluasnya budaya bercocok tanam ganja pada berbagai bangsa dan daerah. Kebutuhan akan pangan, serat untuk tekstil, dan talitemali, minyak untuk penerangan dan energy, hingga obat-obatan untuk berbagai jenis penyakitserta aktivitasaktivitas peradaban lainnya menjadi faktor-faktor evolusioner yang mempererat simbiosis antara ganja dan manusia. Hausnya akan keinginan manusia ini ternyata diimbangi juga dengan kemampuan adaptasi ganja yang menakjubkan. Ganja memiliki sifat alamiah sebagai tanaman liar dan sejarah budidayanya oleh manusia yang diperkirakan lebih dari 12 ribu tahun tidak mengubah sifat dasar ini. Di alam liar, tanaman ganja hampir-hampir tidak memerlukan organisme lain untuk menyebarkan benihnya, tidak memerlukan kondisi tanah yang subur atau iklim yang stabil, tanaman ini hampir dapat tumbuh di segala tempat, ketinggian, cuaca, dan sebaran temperature yang luas.

12 Peter Dantovski, Kriminalisasi Ganja, Lingkar Ganja Nasional \& Indie Book Corner, Yogyakarta, 2013, hlm. 58.

${ }^{13}$ ibid hlm. 59 
Bila ganja dapat tumbuh di daerah yang panas, ia akan memproduksi banyak resin atau getah dari daun bunganya yang merupakan zat psikoaktif untuk menangkap sebanyak mungkin air baik dari hujan maupun embun. Bila ganja tumbuh di daerah yang dingin dan lembab, ia akan menghasilkan batang yang lebih kuat namun getah yang lebih sedikit.

Kedua hal itu menarik kala membandingkan antara sejarah budidaya ganja di Mesir dan India dengan budidaya tanaman ganja di daerah-daerah subtropics seperti Eropa, Rusia, dan Kanada. Bila membandingkan geopolitik peradaban manusia dengan persebaran tanaman ganja, dapat ditangkap bahwa karakteristik jenis ganja yang tumbuh di masing-masing daerah menentukan juga peran dan sumbangannya kepada peradaban setempat. Serat yang kuat memberikan peradaban dalam hal teknologi kepada bangsa-bangsa yang tinggal di daerah subtropics seperti Eropa, Rusia, Cina bagian utara, dan Jepang. Sementara produksi getah yang banyak memberikan sumbangan bagi perkembangan ilmu pengobatan, seni, dan kebudayaan bagi bangsabangsa yang tinggal didaerah tropis atau daerah panas seperti Cina, India, Mesir, dan Arab. Tanaman ganja seperti memahami kebutuhan manusia dalam relasi dengan alam tempat tinggalnya. ${ }^{14}$

\section{Akibat Hukum Dari Penggunaan Ganja Di Indonesia}

Diundangkannya Undang-

Undang Nomor 35 Tahun 2009

Tentang Narkotika menggantikan Undang-Undang Nomor 22 Tahun

\footnotetext{
${ }^{14}$ Ibid, hlm. 60
}

1997 Tentang Narkotika, menunjukan adanya upaya-upaya ke arah pembangunan hukum. Dalam konteks pembangunan hukum menuju kondisi yang lebih baik itu, dapat dirumuskan paling tidak dua hal. Pertama bagian faktor domestik, baik pemerintah maupun masyarakat memainkan peranannya dalam pembangunan tata aturan. Hal ini tentu sangat dipengaruhi oleh ideologi politik hukum atau untuk mudahnya politik pembangunan hukum. Kedua, bagaimana kondisi hukum kedepan dapat menjawab perkembangan global dan regional yang berpengaruh pada paradigma negara dalam menjalankan pembangunan dan pembaruan hukum. ${ }^{15}$

Bunyi Undang-Undang Nomor 35 Tahun 2009 Pasal 1 tersebut dapat dipahami bahwa narkotika merupaka zat atau obat yang berasal dari tanaman atau bukan tanaman, baik sintetis maupun semi sintetis, yang menyebabkan penurunan atau perubahan kesadaran, hilangnya rasa sakit, mengurangi sampai menghilangkan rasa nyeri dan dapat menimbulkan keter-gantungan. Prekusor Narkotika merupakan zat atau bahan pemula atau kimia yang dapat digunakan dalam pembuatan Narkotika. ${ }^{16}$

Secara harfiah narkotika sebagaimana di ungkapkan oleh Wilson Nadaek dalam bukunya "Korban Ganja dan Masalah Narkotika", merumuskan sebagai

15 Adnan Buyung Nasution, Visi Pembangunan Hukum Tahun 2025 Akses Terhadap Keadilan dalam Negara Demokrasi Konstitusional, Jurnal Buah Pena Vol. V/No.4/Agustus 2008.

${ }^{16}$ F Asya, Narkotika dan Psikotropika, Asa Mandiri, Jakarta, 2009, hlm. 3. 
berikut : Narkotika berasal dari bahasa Yunani, dari kata Narke, yang berarti beku, lumpuh, dan dungu. ${ }^{17}$ Menurut farmakologis medis, yaitu "Narkotika adalah obat yang dapat menghilangkan (terutama) rasa nyeri yang berasal dari daerah Visceral dan dapat menimbulkan efek stupor (bengong masih sadar namun harus di gretak) serta adiksi. ${ }^{18}$

Berdasarkan unsur-unsur dalam Pasal 112 ayat (1) Undang-Undang Nomor 35 Tahun 2009 Tentang Narkotika tersebut, dapat diancam pidana penjara paling singkat 4 (empat) tahun dan paling lama 12 tahun dan pidana denda paling sedikit Rp. 800 juta dan paling banyak Rp. 8 miliar jika memang terbukti secara sah memiliki narkotika golongan I ini. Pasal ini tidak memandang apakah berat dari ganja yang dimiliki itu kurang dari 1 (satu) gram atau lebih. Namun, dalam hal orang tersebut memiliki, menyimpan, menguasai, atau menyediakan narkotika golongan I yang beratnya melebihi 5 (lima) gram, maka berdasarkan Pasal 112 ayat (2) Undang-Undang Nomor 35 Tahun 2009 Tentang Narkotika, ancaman pidananya lebih berat, yaitu pidana penjara seumur hidup atau pidana penjara paling singkat 5 (lima) tahun dan paling lama 20 tahun dan pidana denda maksimum sebagaimana disebutkan dalam Pasal 112 ayat (1) ditambah 1/3 (sepertiga). ${ }^{19}$ Kemudian, atas

17 Wilson Nadack, Korban Ganja dan Masalah Narkotika, Indonesia Publishing House, Bandung, 1983, hlm. 122.

18 Wijaya A.W.,Masalah Kenakalan

Remaja dan Penyalahgunaan Narkotika, Amrico, Bandung, 1985, hlm. 145

19 Pasal 112 ayat 1 dan 2 UndangUndang Nomor 35 Tahun 2009 Tentang penggunaan narkotika jenis ganja ini, seseorang dapat disebut sebagai penyalahguna, yakni orang yang menggunakan narkotika tanpa hak atau melawan hukum.

Sebagai orang yang menggunakan narkotika tanpa hak atau melawan hukum, orang tersebut dapat dipidana berdasarkan Pasal 127 ayat (1) huruf a Undang-Undang Nomor 35 Tahun 2009 Tentang Narkotika yang mengatakan bahwa setiap penyalah guna narkotika golongan I bagi diri sendiri dipidana dengan pidana penjara paling lama 4 (empat) tahun. Jika penyalah guna tersebut dapat dibuktikan atau terbukti sebagai korban penyalahgunaan narkotika, penyalah guna tersebut wajib menjalani rehabilitasi medis dan rehabilitasi sosial. $^{20}$

Undang-Undang Narkotika di Indonesia menggunakan istilah penyalahguna narkotika, pecandu narkotika dan korban penyalahgunaan narkotika untuk orang yang menggunakan ganja. Jika seseorang mengalami ketergantungan narkotika, maka orang itu disebut pecandu dan bagi orang yang menggunakan narkotika tapi tidak ketergantungan disebut penyalahguna. Sedangkan korban penyalahgunaan narkotika adalah orang yang menggunakan narkotika karena pengaruh orang lain tanpa ia sadari bahwa itu adalah narkotika. Undang-Undang Narkotika tidak mendefinisikan penggunaan narkotika yang benar untuk keperluan pribadi dengan analogi jika ada istilah penyalahguna, tentu harus ada

\footnotetext{
Narkotika.

${ }^{20}$ Pasal 127 ayat 1 huruf (a) UndangUndang Nomor 35 Tahun 2009 Tentang Narkotika.
} 
kebalikannya, yaitu "pembenarguna". Penggunaan ganja sebagai narkotika golongan I yang dibenarkan dalam Undang-Undang Narkotika hanya boleh untuk keperluan penelitian dan pengembangan IPTEK (Pasal 8 ayat 2 Undang-Undang Nomor 35 Tahun 2009 Tentang Narkotika). ${ }^{21}$

Penyalahgunaan dan peredaran gelap narkotika merupakan masalah sosial sekaligus menjadi masalah hukum dalam masyarakat. Penaggulangan terhadap penyalahgunaan narkotika dilakukan melalui kebijakan yang terarah. Penyalahgunaan narkotika merupakan perbuatan yang bertentangan dengan peraturan perundangan-undangan. Saat ini penyalahgunaan narkotika melingkupi semua lapisan masyarakat baik miskin, kaya, tua, muda, dan bahkan anak-anak.

Penyalahgunaan narkotika dari tahun ke tahun mengalami peningkatan yang akhirnya merugikan kader-kader penerus bangsa. Penyalahgunaan narkotika mendorong adanya peredaran gelap yang makin meluas dan berdimensi internasional. Oleh karena itu diperlukan upaya pencegahan dan penanggulangan narkotika dan upaya pemberantasan peredaran gelap mengingat kemajuan perkembangan komunikasi, informasi dan transportasi dalam era globalisasi saat ini. ${ }^{22}$

Penjelasan umum UndangUndang Nomor 35 Tahun 2009

${ }^{21}$ http://www.lgn.or.id/pentingnyapengetahu-an- hukum-bagi-pengguna-ganja/, diakses pada hari Minggu tanggal 6 Januari 2019, Pukul 15.03 WIB.

22 Lydia Harlina Marton, Membantu Pencandu Narkotika dan Keluarga, Balai Pustaka, Jakarta, 2006, hlm. 1.
Tentang Narkotika mempunyai cakupan yang lebih luas baik dari segi norma, ruang lingkup materi maupun ancaman pidana yang diperberat. Cakupan yang lebih luas tersebut selain didasarkan pada faktor-faktor di atas juga karena perkembangan kebutuhan dan kenyataan bahwa nilai dan norma dalam ketentuan yang berlaku tidak memadai lagi sebagai sarana efektif untuk mencegah dan memberantas penyalahgunaan dan peredaran gelap narkotika. Salah satu materi baru dalam Undang-Undang Nomor 35 Tahun 2009 Tentang Narkotika, dibagi menjadi 3 (tiga) golongan, mengenai bagaimana penggolongan dimaksud dari masingmasing golongan telah di rumuskan dalam Pasal 6 ayat (1) UndangUndang Narkotika.

\section{G. Kesimpulan}

1. Penggunaan ganja tidak hanya untuk kebutuhan sandang dan pangan, bahkan untuk kebutuhan dalam pengobatan berbagai penyakit.

2. Penggunaan ganja di Indonesia masih belum mendapatkan izin dari Pemerintah meskipun ganja digunakan untuk kebutuhan medis dan tidak untuk rekreasi. Pengguna ganja di Indonesia akan tetap diberikan sanksi pidana kurungan dan denda apabila ditemukan pemenuhan unsur yang terdapat dalam Undang-Undang Nomor 35 Tahun 2009 Tentang Narkotika.

\section{H. Saran}

1. Pemerintah segera melakukan riset tanaman ganja agar masyarakat dapat menggunakan ganja 
sebagaimana mestinya tidak harus selalu menjadi persoalan hukum.

2. Adanya pertimbangan hukum dari hakim dalam memutus perkara penggunaan ganja oleh masyarakat yang tujuannya tidak untuk kesenangan, melainkan untuk pengobatan, serta Pemerintah melakukan regulasi UndangUndang Nomor 35 Tahun 2009 Tentang Narkotika ataupun dibuatkannya undang-undang yang mengatur tentang izin penggunaan ganja untuk medis.

\section{DAFTAR PUSTAKA}

\section{Buku :}

Abdul Khaliq, Dunia Dalam Ganja, Penerbit Katalika, Yogyakarta, 2017

Adnan Buyung Nasution, Visi Pembangunan Hukum Tahun 2025 Akses Terhadap Keadilan dalam Negara Demokrasi Konstitusional, Jurnal Buah Pena Vol. V/No.4/Agustus 2008.

Dhira Narayana (et.all), Hikayat Pohon Ganja , PT Gramedia Pustaka Utama, Jakarta, 2011

F Asya, Narkotika dan Psikotropika, Asa Mandiri, Jakarta, 2009

Lydia Harlina Marton, Membantu Pencandu Narkotika dan Keluarga, Balai Pustaka, Jakarta, 2006

Peter Dantovski , Kriminalisasi Ganja, Lingkar Ganja Nasional \& Indie Book Corner, Yogyakarta, 2013

Scott Davidson, Hak Asasi Manusia, Grafiti, Jakarta, 1994
Wijaya A.W.,Masalah Kenakalan Remaja dan Penyalahgunaan Narkotika, Amrico, Bandung, 1985 ,

Wilson Nadack, Korban Ganja dan Masalah Narkotika, Indonesia Publishing House, Bandung, 1983

\section{Peraturan Perundang-undangan:}

Undang-Undang Dasar Negara Republik Indonesia Tahun 1945

Undang-Undang Nomor 35 Tahun 2009 Tentang Narkotika

Internet:

http://derysmono.blogspot.com/2013/ 12/teori-kesehatan.html

http://www.lgn.or.id/pentingnyapengetahuan-hukum-bagipengguna-ganja/, diakses pada hari Minggu tanggal 6 Januari 2019, Pukul 15.03 WIB.

https://www.tni.org/en/publication/ga 
nja-di-indonesia, diakses pada hari Minggu tanggal 09
Desember 2018, pukul 21.08 WIB 